\title{
The 2007 Bengkulu earthquake, its rupture model and implications for seismic hazard
}

\author{
A Ambikapathy, J K Catherine, V K Gahalaut*, \\ M Narsaiah, A Bansal and P MAhesh \\ National Geophysical Research Institute, Council of Scientific and Industrial Research, Hyderabad 500 007, India. \\ *e-mail: vkgahalaut@yahoo.com
}

The 12 September 2007 great Bengkulu earthquake $\left(M_{w} 8.4\right)$ occurred on the west coast of Sumatra about $130 \mathrm{~km} \mathrm{SW}$ of Bengkulu. The earthquake was followed by two strong aftershocks of $M_{w} 7.9$ and 7.0. We estimate coseismic offsets due to the mainshock, derived from near-field Global Positioning System (GPS) measurements from nine continuous SuGAr sites operated by the California Institute of Technology (Caltech) group. Using a forward modelling approach, we estimated slip distribution on the causative rupture of the 2007 Bengkulu earthquake and found two patches of large slip, one located north of the mainshock epicenter and the other, under the Pagai Islands. Both patches of large slip on the rupture occurred under the island belt and shallow water. Thus, despite its great magnitude, this earthquake did not generate a major tsunami. Further, we suggest that the occurrence of great earthquakes in the subduction zone on either side of the Siberut Island region, might have led to the increase in static stress in the region, where the last great earthquake occurred in 1797 and where there is evidence of strain accumulation.

\section{Introduction}

In the region of Sumatra, oblique plate convergence between the India-Australia and Sunda plates at the rate of about $6 \mathrm{~cm} /$ year in the north-eastnorth direction is partitioned into the arc normal motion in the frontal arc and arc parallel motion on the Sumatra fault system in the back arc region (Fitch 1972; McCaffrey 1992; Curray 2005; Gahalaut and Gahalaut 2007; Chlieh et al 2008). Thus thrust earthquakes occur along the subduction zone while strike slip earthquakes occur along the Sumatra fault system. Previous great earthquakes in the Mentawai and Nias regions (figure 1) occurred in $1797\left(M_{w} 8.7-8.9\right), 1833\left(M_{w} 8.9-\right.$ 9.1), and in $1861\left(M_{w} 8.5\right)$ (Lay et al 2005; Natawidjaja 2006; Subarya et al 2006; Chlieh et al 2008; Konca et al 2008). More recently, 2005 Nias earthquake occurred in the source region of 1861 earthquake (Gahalaut and Catherine 2006). The recent Bengkulu earthquake of 12 September 2007
$\left(M_{w}\right.$ 8.4, origin time 11:10:26 UTC) occurred in the source region of 1833 and 1797 earthquakes. The great earthquake was followed by two major earthquakes with $M_{w} 7.9$ on 12 September 2007 at 23:49:03 UTC and $M_{w} 7.0$ on 13 September 2007 at 03:35:28 UTC. The aftershocks that followed the great Bengkulu earthquake occurred in a $300 \mathrm{~km}$ long region between the earthquake epicenter and Sipora Island. The estimated focal mechanisms of the great earthquake and two major aftershocks show thrust faulting, on a plane parallel to the general trend of the trench with a dip of about $12^{\circ}$ (figure 1) at a shallow depth of about $30 \mathrm{~km}$ (Engdahl et al 2007), suggesting that this earthquake occurred in the frontal arc on the plate interface. About 25 persons were killed due to the earthquake. The areas worst hit by this earthquake are the West Sumatra and Bengkulu provinces, including Mentawai Islands. The earthquake generated a moderate near-field tsunami which was destructive at certain locations (Fuji

Keywords. 2007 Bengkulu earthquake; GPS measurements; coseismic displacement; slip model; tsunami. 


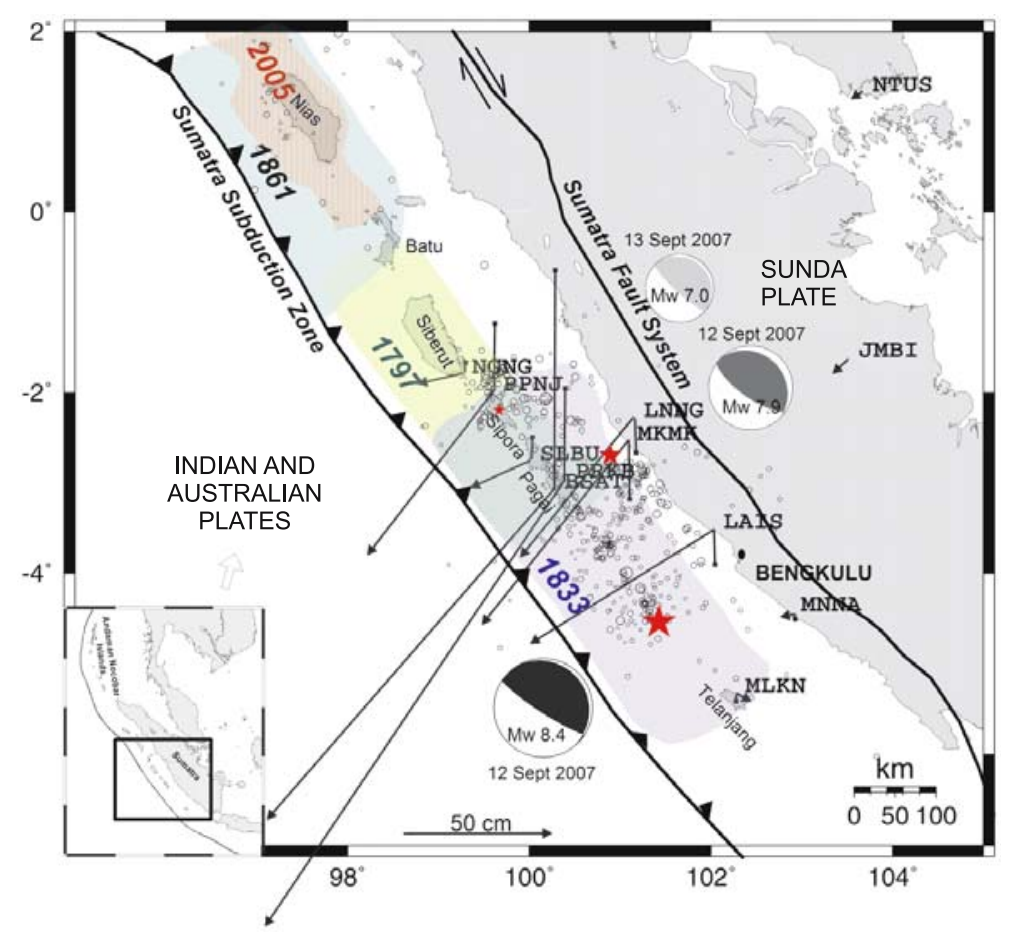

Figure 1. Sumatra subduction zone and the ruptures of historical great earthquakes in the Sumatra forearc region (Lay et al 2005; Natawidjaja et al 2006; Subarya et al 2006; Chlieh et al 2008; Konca et al 2008). The inset at the bottom left corner shows the location of the figure within the Andaman Nicobar and Sumatra subduction zone. The largest red star shows the epicenter of the great 2007 Bengkulu earthquake. Other two red stars show two major aftershocks of $M_{w} 7.9$ and 7.0. Focal mechanisms of these earthquakes are also shown. Aftershocks are shown with black circles. The four letter words show the SuGAr sites where continuous GPS measurements are available. An IGS site, NTUS at Singapore, is also shown. Coseismic offsets due to the mainshock and aftershocks are shown by the arrows. The elevation changes are shown by vertical blunt arrows.

and Satake 2008; Borrero et al 2009). In the farfield, the tsunami was relatively benign with no damaging effects elsewhere in the Indian Ocean.

Here in this article, we estimate the rupture parameters of the earthquake using the available Global Positioning System (GPS) measurements in the source region to analyse its implications in terms of tsunami generation and future seismic hazard in the region.

\section{GPS measurements of coseismic offsets}

A very dense network of continuous GPS stations, Sumatra GPS Array (SuGAr), in the Sumatra region is operated by Tectonics Observatory, California Institute of Technology (Caltech), Lembaga Ilmu Pengatahuan Indonesia, Indonesian Institute of Science (LIPI), and Scripps Orbit and Permanent Array Center (SOPAC). We processed and analysed GPS data using GAMIT/GLOBK software (Herring 2000; King and Bock 2000) in the ITRF2005 reference frame (Altamimi et al 2007) from 12 SuGAr permanent sites (figure 1) that are located within $300 \mathrm{~km}$ of the earthquake epicenter.
We used daily observation files and estimated coordinates of these sites for five days prior to and five days after the earthquake. We also included SAMP (a permanent site operated by BAKOSURTANAL, Indonesia) and other IGS sites surrounding the region. The sampling interval at most of the SuGAr sites is 120 seconds which caused increase in error in the site coordinates. The average error in the horizontal is about $6 \mathrm{~mm}$ and vertical is $15 \mathrm{~mm}$. Low accuracy in the coordinates is mainly due to higher sampling interval of 120 seconds against the usual sampling interval of 30 seconds. We estimated coseismic offsets at all these sites due to the entire earthquake sequence by comparing the coordinates before and after the earthquake sequence (figures 1 and 2). The processing error is insignificant as compared to the coseismic offset derived at these sites. We found that all the above SuGAr sites experienced coseismic movement and at some of these sites even postseismic movement can also be seen (figures 2 and 3 ).

In an attempt to estimate the coseismic displacement due to the 2007 Bengkulu earthquake, we separately processed the GPS observations recorded between the occurrence of the mainshock and the first aftershock of $M_{w}$ 7.9. We could 


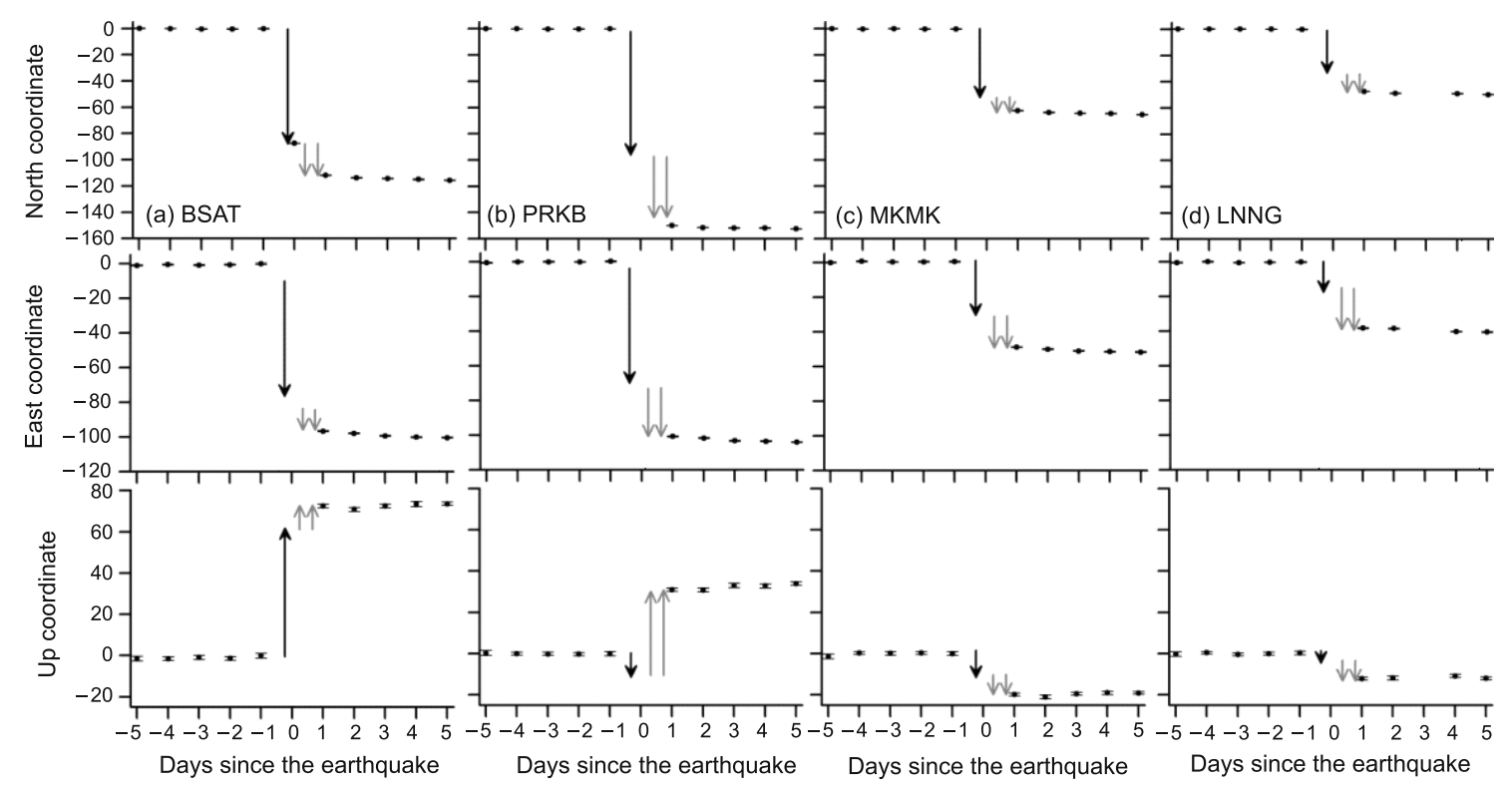

Figure 2. Variation in the north, east and up coordinates at a few selected sites. Black arrow shows the coseismic offset due to the mainshock while two gray arrows show the offsets due to the two aftershocks of $M_{w} 7.9$ and 7.0 .0 on the abscissa denotes the date of the mainshock.

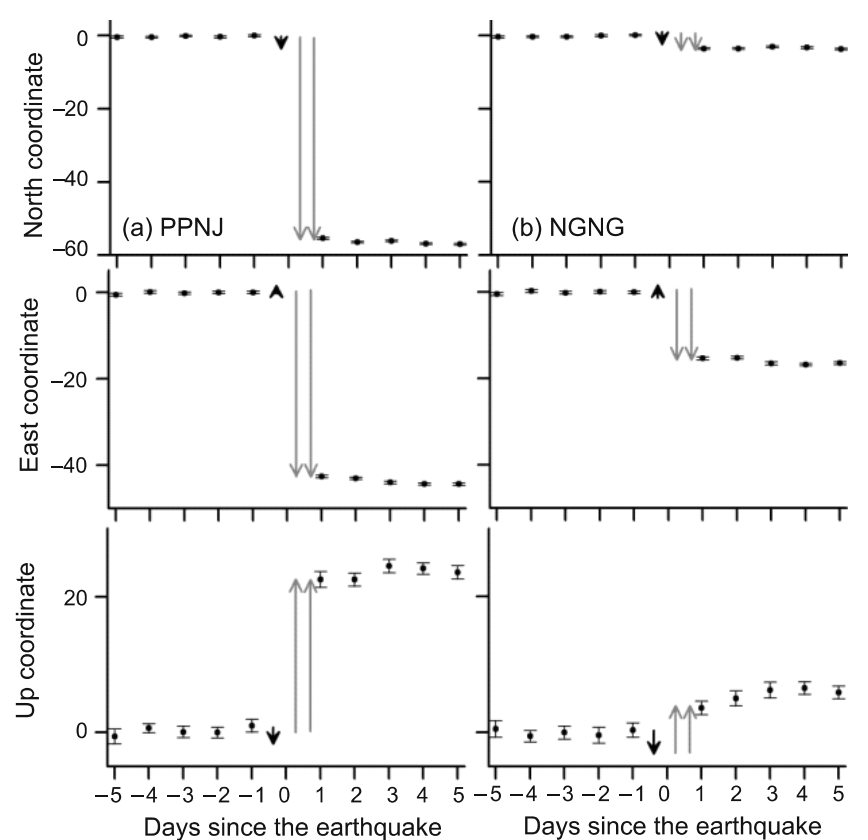

Figure 3. Variation in the north, east and up coordinates at PPNJ and NGNG where coseismic offsets are mainly caused by the two aftershocks of $M_{w} 7.9$ and 7.0 .

estimate the coseismic displacements at six sites (figures 2-4 and table 1). Maximum horizontal displacement of $1.2 \mathrm{~m}$ occurred at a site, BSAT, located at Pagai Island. Coseismic uplift at this site was about $0.61 \mathrm{~m}$. The sites on the island belt experienced uplift whereas those in the coastal Sumatra region experienced subsidence. Two sites, PPNJ and NGNG appear to have affected more by the aftershocks than by the mainshock (figure 3 ).

\section{Analysis of the coseismic offsets and rupture slip model of 2007 Bengkulu earthquake}

The pattern in the aftershocks and coseismic GPS offsets (figure 4) suggest that:

- the 2007 Bengkulu earthquake rupture had a length of about $300 \mathrm{~km}$;

- high slip on rupture occurred somewhere in between the earthquake epicenter and Pagai Island, causing high coseismic displacement at sites at Pagai Island;

- the updip edge of the rupture with high slip lies close to the western coast of the island belt causing high uplift at a site, BSAT, at Pagai Island;

- the downdip edge of the rupture might have extended close to western coast of the Sumatra; and

- rupture probably did not extend up to the trench in the updip direction, as seen from the absence of aftershocks close to the trench and large coseismic uplift at a site BSAT.

In an effort to estimate a slip model consistent with the coseismic offsets derived from GPS measurements, we adopted a forward modelling approach. We used trial and error approach and tried to minimize the discrepancy between the coseismic displacements at simulated sites and that estimated from the GPS measurements. Based on the extent of the region of aftershocks, we assumed a rupture length of $300 \mathrm{~km}$ whose updip edge coincides with the cluster of aftershocks at a depth 


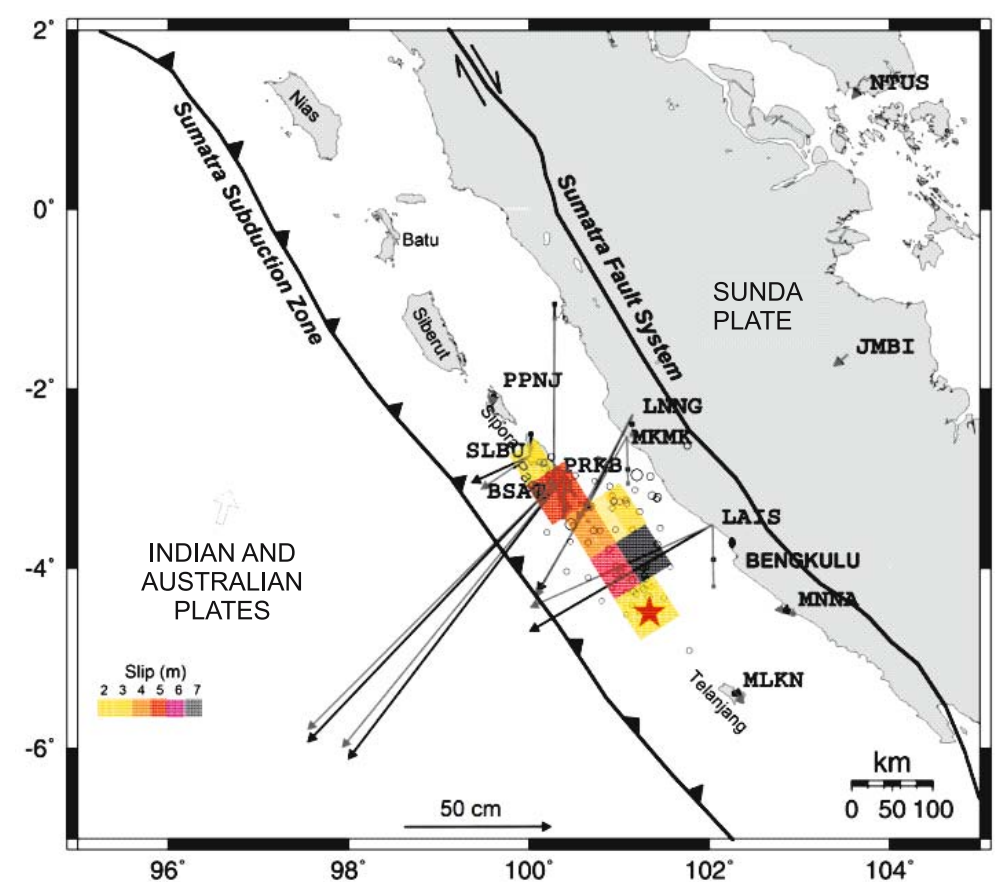

Figure 4. Slip model for the mainshock derived from the modelling of coseismic offsets at SuGAr GPS sites. Coseismic offsets predicted by the model (gray colour arrows) are also shown. Two high slip patches, one north of mainshock epicenter and another under the south Pagai Island region may be noted.

Table 1. Coseismic displacement due to the 2007 Bengkulu earthquake estimated at 10 SuGAr sites, and at two IGS sites, namely, NTUS and COCO. $N_{\text {offset }}$ and $E_{\text {offset }}$ indicate the horizontal displacement in the north and east directions while $U p_{\text {offset }}$ corresponds to vertical displacement.

\begin{tabular}{|c|c|c|c|c|c|c|c|c|c|}
\hline \multirow{2}{*}{$\begin{array}{l}\text { Sl. } \\
\text { no. }\end{array}$} & \multirow[b]{2}{*}{ Site } & \multirow[b]{2}{*}{ Lat. } & \multirow[b]{2}{*}{ Long. } & \multicolumn{3}{|c|}{$\begin{array}{l}\text { Estimated coseismic displacement from } \\
\text { GPS measurements }(\mathrm{cm})\end{array}$} & \multicolumn{3}{|c|}{$\begin{array}{c}\text { Predicted coseismic displacement } \\
\text { using slip model }(\mathrm{cm})\end{array}$} \\
\hline & & & & $\mathrm{N}_{\text {offset }}$ & $E_{\text {offset }}$ & $\mathrm{Up}_{\text {offset }}$ & $\mathrm{N}_{\text {offset }}$ & $E_{\text {offset }}$ & $\mathrm{Up}_{\text {offset }}$ \\
\hline 1. & BSAT & -3.06 & 100.28 & $-87.4 \pm 0.6$ & $-83.3 \pm 0.8$ & $60.8 \pm 3.0$ & -83.1 & -83.3 & 54.5 \\
\hline 2. & $\mathrm{COCO}$ & -12.11 & 96.83 & $0.5 \pm 0.4$ & $0.2 \pm 0.7$ & - & 0.3 & 0.3 & 0.1 \\
\hline 3. & JMBI & -1.60 & 103.52 & $-4.3 \pm 0.6$ & $-4.5 \pm 1.0$ & - & -4.2 & -5.1 & 0.2 \\
\hline 4. & LAIS & -3.50 & 102.03 & $-36.2 \pm 0.6$ & $-61.7 \pm 1.0$ & $-11.7 \pm 3.0$ & -27.8 & -62.1 & -21.8 \\
\hline 5. & LNNG & -2.27 & 101.16 & $-33.2 \pm 0.6$ & $-16.7 \pm 0.6$ & $-3.0 \pm 2.0$ & -36.1 & -18.9 & -7.4 \\
\hline 6. & MKMK & -2.52 & 101.09 & $-52.7 \pm 0.6$ & $-30.4 \pm 1.0$ & $-10.6 \pm 2.0$ & -54.6 & -31.1 & -16.6 \\
\hline 7. & MLKN & -5.32 & 102.28 & $-1.6 \pm 0.6$ & $1.8 \pm 1.0$ & $-1.0 \pm 2.4$ & -2.4 & 1.9 & -1.5 \\
\hline 8. & MNNA & -4.42 & 102.89 & $-0.8 \pm 0.6$ & $-4.0 \pm 1.0$ & $-1.8 \pm 2.4$ & -0.3 & -6.1 & -1.9 \\
\hline 9. & NTUS & 1.34 & 103.68 & $-0.7 \pm 0.4$ & $-0.8 \pm 1.5$ & - & -1.5 & -1.1 & 0.1 \\
\hline 10. & PRKB & -2.95 & 100.39 & $-95.8 \pm 0.6$ & $-73.1 \pm 0.8$ & $-11.2 \pm 2.6$ & -92.3 & -75.1 & -20.5 \\
\hline 11. & SLBU & -2.75 & 100.01 & $-9.2 \pm 1.0$ & $-20.2 \pm 2.0$ & $7.4 \pm 4.0$ & -11.6 & -16.9 & 3.3 \\
\hline
\end{tabular}

of $13 \mathrm{~km}$ and whose downdip edge lies at a depth of $40 \mathrm{~km}$. We assumed the dip of the rupture to be $12^{\circ}$. We divided this rupture into 28 subfaults (4 along the width and 7 along the length) and estimated slip on these subfaults using trial and error method in such a way that the discrepancy between the GPS estimated coseismic offsets and predicted offsets decreases. Predominantly reverse slip occurred during this earthquake. We estimated two patches of maximum slip of 6-7 $\mathrm{m}$ occurred under the Pagai Island and about $200 \mathrm{~km} \mathrm{NW}$ of mainshock epicenter (figure 4). The average root mean square (rms) error for this model is $3.3 \mathrm{~cm}$. The high slip region under the Pagai Island is consistent with the high seismic coupling in the region, as inferred by Chlieh et al (2008) on the basis of interseismic geodetic data.

Though we adopted a fairly simple forward modelling procedure, our rupture model is consistent with a recently published model (Konca 


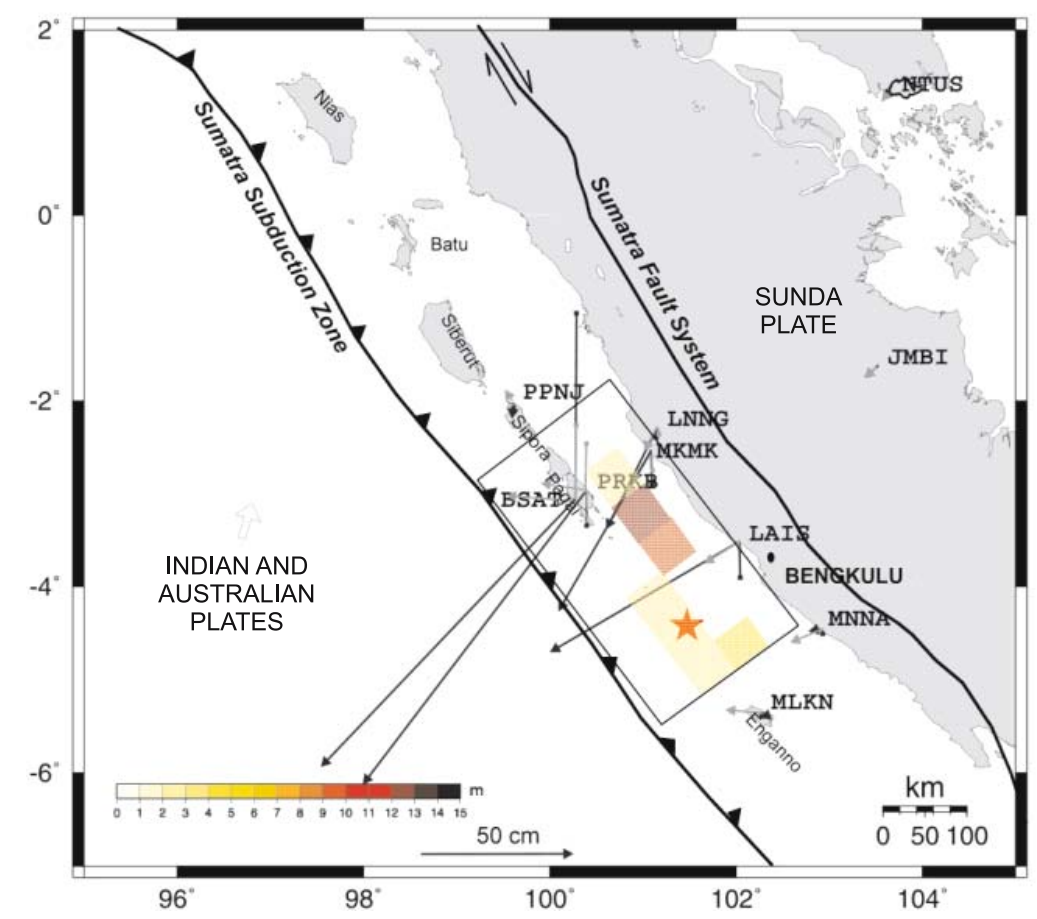

Figure 5. Slip model of Lorito et al (2008) and the coseismic offsets predicted by the model (gray colour arrows). It can be seen that the predicted coseismic offsets are much smaller than those estimated from the SuGAr measurements.

et al 2008) which involved inversion of GPS measurements, field measurements of observed coseismic uplift, Synthetic Aperture Radar (SAR) interferometry and seismic waveforms of the earthquake. Our rupture model yields a moment magnitude $\left(M_{w}\right)$ for this earthquake as 8.3. Our lower estimated value of $M_{w}$, against the 8.4 estimated by Konca et al (2008), could be due to the lower dip of rupture assumed by us. Konca et al (2008) used a dip of $15^{\circ}$ thus pushing the rupture to lower depth. Moreover, Konca et al (2008) used additional data to constrain the slip model and $M_{w}$.

Lorito et al (2008) reported a rupture model for the earthquake based on the tsunami waves recorded at tide gauge stations. They indicated thrust slip on the $12^{\circ}$ dipping plate boundary interface with high slip reaching $13-14 \mathrm{~m}$ on a patch southeast of the Pagai Island. We tested whether this model is consistent with the coseismic offsets derived from GPS measurements. Figure 5 shows the response of their model at SuGAr sites. The average rms error for this model is $52.3 \mathrm{~cm}$. Clearly, their model predicts very low coseismic offset at sites which experienced very high offsets. The apparent reason for such a misfit is that the single high slip patch proposed by them lies southeast of the sites at the South Pagai Island where highest coseismic offsets occurred. Similar situation applies to the slip model proposed by $\mathrm{C} \mathrm{Ji}$ (http://www.geol.ucsb.edu/faculty/ji/ big_earthquakes/2007/09/sumatra_seismic.html) derived from seismic waveforms. In this model the two high slip patches are located even farther southeast of the Pagai Island and the slip amount is very less (maximum being only $3.5 \mathrm{~m}$ ). Even this model predicts less coseismic offsets at sites on the Pagai Island and hence is not consistent with the coseismic offsets derived from GPS measurements. However, the model derived from combined GPS measurements, field measurements of observed coseismic uplift, Synthetic Aperture Radar interferometry and seismic waveforms of the earthquake (Konca et al 2008) is consistent with our model.

We suggest that the derived slip model here or that of Konca et al's (2008) represents the actual slip distribution during the earthquake. The rupture model derived from tsunami waveform data may not be sensitive to the additional northern slip patch under the island belt and shallow water. So if there was high slip on the rupture under the island belt and surrounding shallow water region, this region would not have displaced large volume of water and hence did not contribute significantly in tsunami generation (Geist et al 2006). Thus the tsunami waveform data at the tide gauge stations could not adequately resolve slip under the island belt and shallow water. The slip model derived from seismic waveform data alone is not very sensitive to the location of high slip patch as it is derived from far-field data from stations at teleseismic distances. 


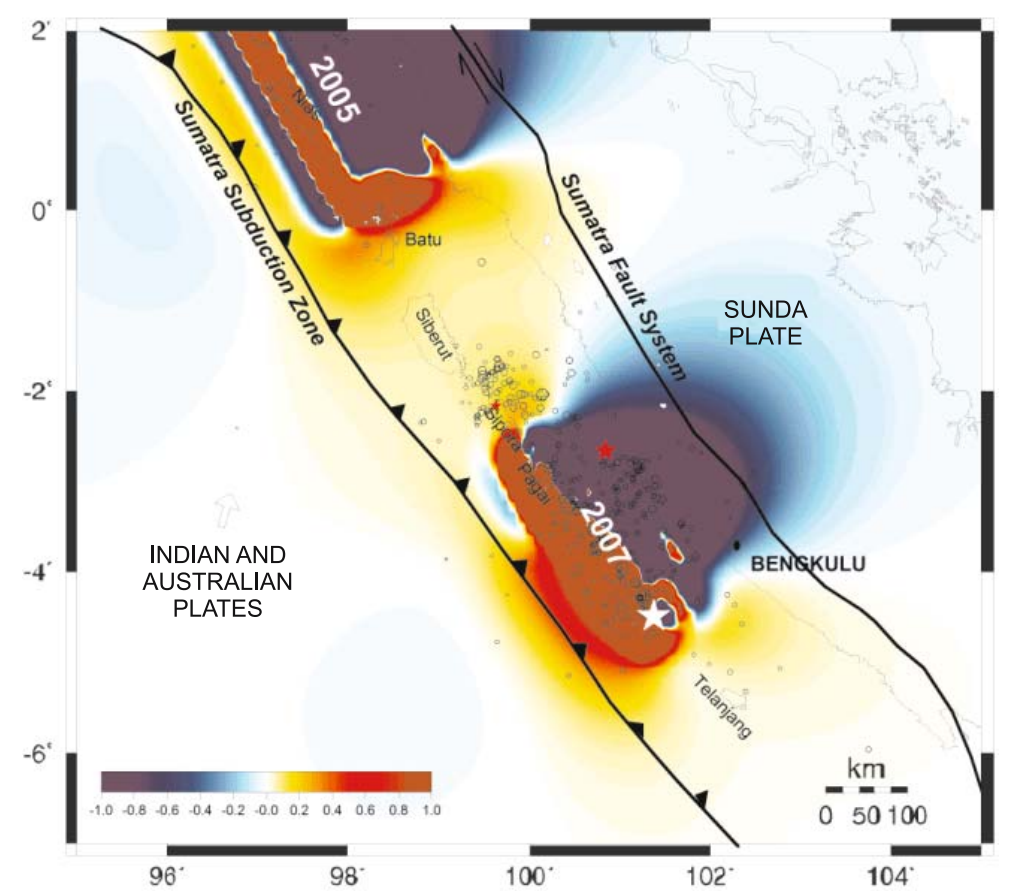

Figure 6. Static stress change (in bars) on optimally oriented planes in the region, caused by the 2005 Nias and 2007 Bengkulu earthquakes. High stress in the Siberut Island region may be noted.

\section{Seismic hazard in Siberut Island region}

Seismic hazard in the Siberut Island region is a matter of concern as in this region the last great earthquake occurred in 1797. The rupture of the 2007 Bengkulu earthquake occurred in the region where ruptures of the great earthquakes of 1833 and 1797 overlapped (Natwidjaja et al 2006). The 2007 rupture did not extend beneath the Siberut Island region. The rupture of the 2005 Nias earthquake occurred in the region of 1861 earthquake, which is to the NW of the Siberut Island region. Thus no great earthquake has occurred in the Siberut region in the past 200 years and there are indications of strain accumulation in the region (Prawirodirdjo et al 1997; McCaffrey 2002; Simoes et al 2004). The occurrence of two great earthquakes in frontal arc on either side of the Siberut Island region may have increased static stress (Toda et al 2005) in the region, in a way similar to the case where 2004 Sumatra Andaman earthquake increased stress in the rupture zone of 2005 Nias earthquake (Gahalaut and Kalpna 2005; McClosky et al 2005). We calculate the Coulomb stress using the slip model of 2005 Nias earthquake (Briggs et al 2006; Gahalaut and Catherine 2006; Hsu et al 2006) and the slip model of the 2007 Bengkulu earthquake, derived here (figure 6). The two earthquakes on either side of the Siberut region have clearly increased stress in this region, thus bringing this region of high seismic coupling
(Chlieh et al 2008) further closer to the failure than it was before the occurrence of the two earthquakes (Borrero et al 2006). In fact the largest magnitude aftershock $\left(M_{w} 7.9\right)$ that followed the mainshock after 12 hours, occurred in the increased stress region (figure 6). Due to the non-availability of the detailed rupture parameters for this aftershock, we did not asses its effect on the Siberut region. However, as even this aftershock had similar focal mechanism (figure 1) as that of the mainshock, we suggest that even this aftershock increased the stress in the Siberut region.

\section{Conclusions}

The 2007 Bengkulu earthquake occurred in a region of dense GPS network. These measurements provided estimates of high coseismic displacements reaching $1.2 \mathrm{~m}$. The modelling of these near-field data suggests that the $250 \times 100 \mathrm{~km}^{2}$ earthquake rupture on the gently dipping plate interface had a maximum slip of $7 \mathrm{~m}$ under the Pagai Island. Majority of the slip on the rupture was confined in the depth range of $13-40 \mathrm{~km}$ and the rupture did not extend till the trench. The earthquake, despite its large size, did not generate a major tsunami as most of the high slip occurred under the islands and shallow water, so that the volume of the water displaced by the coseismic uplift was very less to cause any major tsunami. From the historical records of great earthquakes in the region, 
it appears that the recurrence interval of the great earthquake in the region is about 150 years (varying from 144 years in Nias to 174 years in Sipora and Pagai Island regions), as the last earthquake in this region occurred in 1833 (Natawidjaja et al 2006). If that applies to the Siberut Island region as well, then even this region may experience great earthquake sooner. In fact occurrence of 2005 Nias and 2007 Bengkulu earthquakes might have already increased the stress in this region.

\section{Acknowledgements}

We benefited from encouraging reviews from three anonymous reviewers. We thank the scientists and technicians of the Tectonics Observatory, Caltech, LIPI and SOPAC, who establish, maintain and operate the array. This work was supported by MoES.

\section{References}

Altamimi Z X, Collilieux J, Legrand B, Garayt and Boucher C 2007 ITRF2005: A new release of the International Terrestrial Reference Frame based on time series of station positions and Earth Orientation Parameters; J. Geophys. Res. 112 B09401, doi: 10.1029/ 2007JB004949.

Briggs R, Kerry Sieh, Aron J Meltzner, Danny Natawidjaja, John Galetzka, Bambang Suwargadi, Ya-ju Hsu, Mark Simons, Nugroho Hananto, Imam Suprihanto, Dudi Prayudi, Jean-Philippe Avouac, Linette Prawirodirdjo and Yehuda Bock 2006 Deformation and slip along the Sunda megathrust in the great 2005 Nias-Simeulue earthquake; Science 311 1897-1901.

Borrero J C, Kerry Sieh, Mohamed Chlieh and Synolakis C E 2006 Tsunami inundation modeling for western Sumatra; Proc. Nat. Acad. Sci. (PNAS) 103 19,673-19,677.

Borrero J C, Weiss R, Okal E A, Hidayat R, Suranto, Arcas D and Titov V V 2009 The tsunami of 2007 September 12, Bengkulu province, Sumatra, Indonesia: Post-tsunami field survey and numerical modeling; Geophys. J. Int. 178 180-194.

Chlieh M, Avouac J P, Sieh K, Natawidjaja D H and Galetzka J 2008 Heterogeneous coupling of the Sumatran megathrust constrained by geodetic and paleogeodetic measurements; J. Geophys. Res. 113 B05305, doi:10.1029/2007JB004981.

Curray J R 2005 Tectonics and history of the Andaman sea region; J. Asian Earth Sci. 25 187-228.

Engdahl E R, Antonio Villaseñor, Heather R DeShon and Clifford $\mathrm{H}$ Thurber 2007 Teleseismic relocation and assessment of seismicity (1918-2005) in the region of the $2004 M_{w}$ 9.0 Sumatra-Andaman and $2005 M_{w} 8.6$ Nias Island great earthquakes; Bull. Seismol. Soc. Am. 97 S43-S61, doi: 10.1785/0120050614.

Fitch T J 1972 Plate convergence, transcurrent faults and internal deformation adjacent to Southeast Asia and the western Pacific; J. Geophys. Res. 77 4432-4460.

Fujii Y and Satake K 2008 Tsunami waveform inversion of the 2007 Bengkulu, southern Sumatra earthquake; Earth Planets Space 60 993-998.
Gahalaut V K and Kalpna 2005 March, 28, 2005 Sumatra earthquake: Expected, triggered or aftershock?; Curr. Sci. 89 452-454.

Gahalaut V K and Catherine J K 2006 Rupture characteristics of 28 March 2005 Sumatra earthquake from GPS measurements and its implication for tsunami generation; Earth Planet. Sci. Lett. 249 39-46.

Gahalaut V K and Gahalaut K 2007 Burma plate motion; J. Geophys. Res. 112 B10402, doi:10.1029/ 2007JB004928.

Geist E, Bilek S, Arcas D and Titov V V 2006 Differences in tsunami generation between the December 26, 2004 and March 28, 2005 Sumatra earthquakes; Earth Planets Space 58 185-193.

Herring T 2000 Global Kalman Filter VLBI and GPS Analysis Program (GLOBK), version 5.0. Mass. Inst. of Technol., Cambridge, Mass.

Hsu Y, Mark Simons, Jean-Philippe Avouac, John Galetzka, Kerry Sieh, Mohamed Chlieh, Danny Natawidjaja, Linette Prawirodirdjo and Yehuda Bock 2006 Frictional afterslip following the $M_{w} 8.7,2005$ Nias earthquake, Sumatra; Science 312 1921-1926, doi:10.1126/ science.1126960.

King R and Bock Y 2000 Documentation for the GAMIT GPS Analysis Software, Release 9.94. Mass. Inst. of Technol., Cambridge, Mass and Scripps Inst of Oceanogr, La Jolla, Calif.

Konca A, Avouac J-P, Sladen A, Meltzner A J, Sieh K, Fang P, Li Z, Galetzka J, Genrich J, Mohamed Chlieh, Danny H Natawidjaja, Yehuda Bock, Eric J Fielding, Chen Ji and Don V Helmberger 2008 Partial rupture of a locked patch of the Sumatra megathrust during the 2007 earthquake sequence; Nature 456 631-635.

Lay T, Hiroo Kanamori, Charles J Ammon, Meredith Nettles, Steven N Ward, Richard C Aster, Susan L Beck, Susan L Bilek, Michael R Brudzinski, Rhett Butler, Heather R DeShon, Göran Ekström, Kenji Satake and Stuart Sipkin 2005 The Great Sumatra-Andaman Earthquake of 26 December 2004; Science 308 1127-1133.

Lorito S, Romano F, Piatanesi A and Boschi E 2008 Source process of the September 12,2007, $M_{w} 8.4$ southern Sumatra earthquake from tsunami tide gauge record inversion; Geophys. Res. Lett. 35 L02310, doi:10.1029/ 2007GL032661.

McCaffrey R 1992 Oblique plate convergence, slip vectors, and forearc deformation; J. Geophys. Res. 97(B6) 8905-8915.

McCaffrey R 2002 Crustal block rotations and plate coupling; In: Plate boundary zones (eds) Seth Stein and Freymueller J T, Geodynamic Series, AGU, Washington D.C. $30101-122$.

McCloskey J, Nalbant S S and Steacy S 2005 Earthquake risk from coseismic stress; Nature 434291.

Natawidjaja D H, Sieh K, Chlieh M, Galetzka J, Suwargadi B, Cheng H, Edwards R L, Avouac J-P and Ward S N 2006 Source parameters of the great Sumatran megathrust earthquakes of 1797 and 1833 inferred from coral microatolls; J. Geophys. Res. 111 doi:10.1029/2005JB004025.

Prawirodirdjo L, Bock Y, McCaffrey R, Genrich J, Calais E, Stevens C, Puntodewo S S O, Subarya C, Rais J, Zwick P and Fauzi 1997 Geodetic observations of interseismic strain segmentation at the Sumatra subduction zone; Geophys. Res. Lett. 24(21) 2601-2604, doi:10.1029/97GL52691.

Simoes M, Avouac J P, Cattin R and Henry P 2004 The Sumatra subduction zone: A case for a locked fault zone extending into the mantle; J. Geophys. Res. 109 B10402, doi:10.1029/2003JB002958. 
Subarya C, Mohamed Chlieh, Linette Prawirodirdjo, Jean-Philippe Avouac, Yehuda Bock, Kerry Sieh, Aron J Meltzner, Danny H Natawidjaja and Robert McCaffrey 2006 Plate-boundary deformation associated with the great Sumatra-Andaman earthquake; Nature 440 46-51.
Toda S, Stein R S, Richards-Dinger $\mathrm{K}$ and Bozkurt S 2005 Forecasting the evolution of seismicity in southern California: Animations built on earthquake stress transfer; J Geophys. Res. B05S16, doi:10.1029/ 2004JB003415.

MS received 11 November 2009; revised 4 May 2010; accepted 4 May 2010 